\title{
Measuring Announcement Effect of Refinancing: Evidence from Chinese Public Utility Listed Companies
}

\begin{abstract}
${ }^{*}$ Ziyi Zhang ${ }^{1}$
'College of (Civil Lngineering, Oregon State Iniversity, ('orivillis, Oregon, Inited States

Refinancing is generally regarded as a major financing source of Chinese listed companies. The purpose of this study was to investigate the capital structure from the perspective of increment by measuring the announcement effect. This study identified 110 public utility firms listed on the A-share stock market. Using the event study methodology, this study implemented empirical analysis on the announcement effect of three refinancing modes i.e., secondary equity offerings (SEOs), issuing ordinary bonds, and issuing convertible bonds, measured by the abnormal returns. This study discovered that SEOs had a significant negative announcement effect, issuing bonds had a significant positive announcement effect, and issuing convertible bonds had a negative but not significant announcement effect. Our results indicated that SEOs are associated with negative market reactions and issuing bonds convey positive signals to the markets. These findings were similar to prior studies on the Chinese stock market as a whole in term of signs but are different in term of magnitudes.

Keywords: Public utility company, equity refinancing, debt refinancing, announcement effect, capital structure

JEL: G14, G32
\end{abstract}

With the rapid urbanization in China, there exist severe fiscal problems of local government for their high leverage, which are induced by increasing public utility investment. To solve this problem, it would be beneficial to raise funds from the public through initial public offerings (IPOs) for state-owned enterprises (SOEs). However, it is quite common that financing channels are insufficient in Chinese context, which makes refinancing an effective way to raise funds, optimize capital structure, and improve the corporate profitability (Danis, Rettl and Whited, 2014; Di Maggio et al., 2016; Moldogaziev and Luby, 2012).

This study is theoretically motivated by the information asymmetry in the association between capital structure and firm value (Cuong, 2014; Hossain and Neuyen, 2016; Myers and Majluf, 1984; Sheikh and Wang, 2011). To formalize the information effect of the adjustment of capital structure, they propose that managers have more information about the firm value than external investors. Thus, managers have an incentive to issue equities when firms are overvalued. On the contrary, managers incline to issue bonds when firms are undervalued. Generally, equity refinancing often has a negative announcement effect on stock prices, while debt refinancing often has a positive announcement effect on stock prices (Ammann, Blickle and Ehmann, 2017; Chin and Abdullah, 2013; Li et al., 2016).

Manuscript received July 5, 2020; revised October 5, 2020; accepted November

15, 2020. @ The Author(s); CC BY-NC; Licensee IJMESS

*Corresponding author: 18811311646@163.com 
International Journal of Management, Economics and Social Sciences

However, scholars usually take the listed firms wholly as the research object, which ignores the large differences across industries. By focusing on the public utility industry, a homogeneous group of firms can be selected for further analysis. Public utility firms mainly consist of tangible assets. Moreover, their firm characteristics (e.g., leverage, firm risk, production technologies) are similar making researchers to better measure the announcement effect.

The announcement effect refers to the significant positive or negative change of the stock price in short-term (several trading days before and after the announcement) after the listed company announces some information to the market (Dolley, 1933). This effect is mainly characterized by abnormal returns from stock price changes using the event study methodology. Hence, this relationship could also be viewed as the announcement effect on shareholder value or firm value. Most current studies mainly concentrated on equity refinancing, while present study also incorporated the debt refinancing into the measurement framework, and identified three main refinancing modes (second equity offerings (SEOs), issuing ordinary bonds, and issuing convertible bonds).

Therefore, this study aims to address the question whether and how corporate refinancing affects the firm value/shareholder value within the public utility industry? It would be beneficial to investigate and measure the announcement effect of refinancing of public utility listed companies to seek out the impact of capital structure adjustment on its value; on the other hand, this study provides empirical evidence for public utility listed companies to make better refinancing decisions. In summary, the main contribution of this study is to provide a precise measurement of refinancing announcement effect of three aforementioned refinancing modes in the public utility industry.

The remainder of this paper is revealed as follows: Section 2 reviews the extant literature focusing on the equity and debt refinancing announcement effects. Section 3 shows the methodology. Section 4 gives an empirical analysis. Section 5 discusses the findings. Section 6 presents conclusion. Section 7 and 8 present implications, and limitations and future directions, respectively.

\section{LITERATURE REVIEW}

\section{Theoretical Underpinnings}

\section{-Asymmetric Information Theory}

Many previous studies have detected the impact of refinancing announcement on stock prices. Lucas and Mcdonald (1990) proposed the theory of adverse selection and market selection based on the asymmetric information model. They assume that if the current stock price is overvalued, management will choose to issue new shares. Otherwise, management will not issue new shares. This opportunistic behavior means that only overvalued companies will issue new shares, so the stock price will fall after 


\section{Zhang}

the announcement.

\section{-Signaling Theory}

Ross (1977) believes that the management's compensation is often linked to the company's market value, and management has incentives to increase the stock price of the company by increasing debt, thereby maximizing their own compensation. His model proves that the marginal benefit of the management's excessive improvement of the asset-liability ratio (transmitting the wrong signal) is less than the marginal cost (the company's bankruptcy, its own compensation loss). The high leverage ratio is a good signal for the company's operating conditions, and its bankruptcy costs and agency costs are unaffordable for companies with poor operating conditions. Therefore, management will truly signal the market by adjusting the company's financial leverage. The issuance of stocks reduces the company's asset-liability ratio. The interpretation by market is that the company's value is reduced, thus selling stocks, hence making stock prices fall.

Comparatively, the research on refinancing announcement effect in public utility companies is limited. Because utility industry is traditionally regarded as a regulatory industry and thus excluded by empirical corporate finance (Booth and Chang, 2011). Asquith and Mullins (1986) selected companies listed on the New York stock exchange from 1963 to 1981 as the sample. The cumulative abnormal return $(C A R)$ rate of industrial stocks in the event window $(-1,0)$ was -2.7 percent. The cumulative abnormal return (CAR) rate of public utility stocks in the event window $(-1,0)$ was -0.9 percent. According to the mentioned theoretical underpinnings, it can clearly be observed that the impact of refinancing (including SEOs, issuing ordinary bonds, and issuing convertible bonds) on stock prices has been well studied. However, the gap within these studies is that most of these studies neglected the impact of refinancing on stock prices within public utility companies, which needs to be further investigated comprehensively.

\section{-Hypotheses Development}

According to both the information asymmetry theory (Lucas and Mcdonald, 1990; Myers and Majluf, 1984) and the signaling theory (Ross, 1977), issuing bonds convey positive information to the markets and issuing equities convey negative information to the markets, which should raise and dampen the stock prices, respectively. More recent studies have provided ample evidence on the capital structure, equity/bond issuances, and stock prices.

Danielova and Smart (2012) stated that issuers use private information to refinance when stock prices are overvalued, which dampens the stock price after issuing new shares. Masulis and Korwar (1986) used the issuance of new shares of listed companies from 1963 to 1980 as samples, and the 
cumulative abnormal (CAR) returns $(-3.25 \%)$ of firms in the manufacturing industry were greater than that of firms in the utility industry $(-0.68 \%)$. They believed the reason is partially stemming from the predictability of the refinancing of public utility companies. On the other hand, Dong, Hirshleifer and Teoh (2012) found that equity issuance increased with firm overvaluation. Hence, we hypothesize that firms conducting SEO when they believe the firms are overvalued, which disseminates negative signals to the markets, resulting in negative effect on stock returns. Therefore, the following hypothesis is proposed:

$\mathrm{H}_{1}$ : Second equity offering (SEO) has a significant negative announcement effect on stock returns.

Apart from the Modigliani-Miller (M\&M) theorem that suggests a positive relationship between leverage and firm value, recent studies also provide novel evidence on stock returns and leverage. For instance, Friewald, Nagler and Wagner (2018) suggested that stock returns increase with leverage and the intensity of debt refinancing. Meanwhile, Cheng, Liu and Chien (2010) documented an inverted-U relationship between leverage and firm value, and before the threshold, debt financing can improve the firm value. Based on the firm characteristics, Ibhagui and Olykoyo (2018) found that small-size firms benefit less from debt financing. In summary, as debt financing would provide benefits to firm longterm performance, we can predict that issuing bonds would have a positive effect on stock returns. Therefore, the following hypothesis is proposed:

$\mathrm{H}_{2}$ : Issuance of ordinary bonds has a significant positive announcement effect on stock returns.

As convertible bonds have the characteristics of both equities and bonds, we cannot find consistent evidence about the announcement effects of convertible bonds. For instance, Duca et al. (2012) reported that after issuing convertible bond, the average abnormal return was -1.69 percent between 1984 and 1999, and the announcement effect would be more than twice as negative $(-4.59 \%)$ between 2000 and 2009, both of which are associated with macroeconomic conditions. Abdul, Goodacre and Veld (2012) reported an abnormal return of -3.3 percent in convertible bond, and concluded that the private information utilized by the issuer is the cause of the negative abnormal return. Kim and Han (2019) investigated the announcement effect of issuing convertible bond in Korea, they concluded that issuing convertible bond is negatively related to stock price, one exception is that positive abnormal returns existed in a sample of listed companies with high trading volume. Chang et al. (2019) found that when firms have investment plans, the issuance of convertible bonds 


\section{Zhang}

will be positively related to the long-term firm performance. Similarly, Ammann et al. (2017) found that the announcement of issuing convertible bonds correlates with positive abnormal stock returns within the banking industry. In summary, the announcements effects of convertible bonds can be ambiguous. Based on the characteristics of convertible bonds, we propose the following hypothesis:

$\mathrm{H}_{3}$ : Issuance of convertible bonds has no significant announcement effect on stock returns.

\section{METHODOLOGY}

\section{Sample and Procedure}

Due to the lack of a clear classification of public utility listed company in China (Chen, Lee and Li, 2008), this study performed a more comprehensive and systematic classification of public utility companies based on the definition of public utility and the general industry classification criteria from China Securities Regulatory Commission (CSRC). This study selected nine secondary industries (i.e., railway, bus, highway, airport, port, electricity, water, gas, and environmental protection). The selected firms had issued equities/bonds/convertible bonds during the period of 2005 to 2018 . Consequently, 134 companies belonging to the nine secondary industries were enrolled in the sample. 14 companies were excluded because they were listed in the small and medium board or growth enterprise market; 10 companies whose main business income was not from the public utility service were also eliminated; finally, 110 companies were enrolled in the final sample.

The study used the announcement day as the event day as suggested by Bartov, Lindahl and Ricks (1998), Shahid et al. (2010), and Suwanna (2012). The public issuance of a listed company must first go through the board of directors to initiate a plan for the issuance. Then the information would be disclosed to the public in the form of an announcement. For the issuance process of Chinese corporate bonds, if the official issuance date is $t$ day, the listed company will usually publish the prospectus and its summary on $t-2$ day, and release the issuance announcement. On $t-1$ day, the coupon rate will be initially determined through roadshows and intentional inquiry. Information on the final coupon rate, the original shareholders' priority placement date, online and offline subscription dates, etc. will be announced on $t$ day. The final coupon rate announced on $t$ day is the key information for determining financing costs. Hence, $t$ day was selected as the event day. Similar to issuing bonds, On the day of the issuance announcement, the market can obtain comprehensive information on the issuance of convertible bonds through the bond prospectus provided by the listed company and the final coupon rate. Therefore, the release announcement date is also a very important point in time. 
The announcement information about issuing equities, bonds, and convertible bonds was obtained from Wind database, whereas the stock price data were obtained from China Stock Market and Accounting Research (CSMAR) database.

\section{Model Specifications}

In order to examine the impact of the refinancing event on stock price, this paper employed event study to investigate whether the occurrence of the event causes the stock price to produce statistically significant abnormal returns, thus testing the response of individuals in market response to the refinancing event. Ball and Brown (1968) made a fundamental contribution to this methodology when studying the information content of the earnings announcement. Brown and Warner $(1980,1985)$ revised the statistical methods implemented in event study. The event study focuses on the special events affecting the stock price, and observes the impact of specific events on the stock's abnormal returns by calculating the stock price changes around the date of the event. It is a kind of statistical analysis that can make good use of the statistical information before and after the event, which has been widely used in economics, finance, accounting, and even law, and is commonly used by scholars studying the effect of refinancing announcement.

The basic idea of event study is to summarize large samples according to the event day. Since the samples have common characteristics on the event day, the influence of other information on the stock price can be positive or negative or can cancel each other, thus can be observed by the sample on the event day. Abnormal returns caused by common characteristics that exceed the normal range of stock price fluctuations. This methodology has advantages as the measure of an event's economic effect can be estimated within a relatively short time period. On the contrary, direct performance related measures will require months or even years of observations. Even worse, a longer time of observation will introduce more noises to draw plausible conclusions.

Firstly, we selected the announcement date of SEOs, the announcement date of issuing convertible bond, and the announcement date of issuing ordinary bonds as the event day. The event window comprised of 20 days before and after the event date, considering that the release of new information may be leaked beforehand, and the new information may continue to have an impact on the stock price after the release. In other words, the event window $(-20,20)$ contained 41 unique trading days and the market model was used to calculate normal returns. The estimation period duration was 240 trading days before the event window. So, the estimation window would be $(-260,-21)$. Figure 1 showcases the event study timeline.

In summary, we used abnormal returns $(A R)$ and cumulative abnormal returns (CAR) to estimate the announcement effects of issuing bonds and equities. 


\section{Zhang}

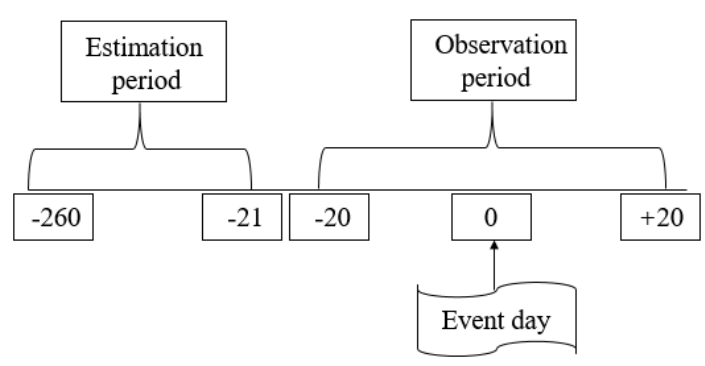

Source: Author's Presentation

Figure 1. Event Study Timeline

\section{Description of Variables}

We followed mainstream event study literature (e.g., Sam and Zhang, 2020) and used the market model to estimate the abnormal returns. The estimation period and observation period were defined in the above section.

Before measuring the abnormal returns, firstly, daily rate of return of a stock was expressed as $R_{t}=\left(P_{t}-P_{t-1}\right) / P_{t-1}$. In order to eliminate the impact of stock splits, allotment, share offerings, and cash dividends on stock prices, this study used the closing price after reinstatement to calculate the yield. Second, abnormal return (AR) and cumulative abnormal return (CAR) were calculated as follows:

$$
\begin{aligned}
& A R_{i t}=R_{i t}-N R_{i t} \\
& C A R_{t t}=\sum_{i=0}^{t} A R_{i j}
\end{aligned}
$$

where $A R_{i t}$ denotes the abnormal rate of return of stock $i$ in period $t$ and $N R_{i t}$ is the normal rate of return of stock $i$ in period $t$, which is estimated using the market model. $C A R_{t t}$ represents the sum of abnormal returns during different event windows in present study.

\section{ANALYSIS AND RESULTS}

According to the above-mentioned event study method, the event day was the $0^{\text {th }}$ day, 20 trading days before and after the event was taken as the event window, and the fluctuation law of the stock price in the 41 days was examined. If there was a suspension within the 20 trading days, this study used the transaction data of former (or later) day instead. Study applied two-tailed $t$-test to examine the significance of single-day abnormal return (AR) and cumulative abnormal return (CAR) (Brav, 
Geczy and Gompers, 2000).

The single-day abnormal returns of SEOs within the event window $(-2,2)$ is shown in Table 1. Moreover, an intuitive result of average abnormal return (AAR) and average cumulative abnormal return (ACAR) is shown in Figure 2.

\begin{tabular}{ccccccc}
\hline Relative date & Mean & Maximum & Minimum & SD & $t$-value & Sig. \\
\hline-2 & -0.007 & 0.019 & -0.006 & 0.010 & -1.344 & 0.191 \\
-1 & -0.010 & 0.021 & -0.025 & 0.012 & -2.763 & 0.011 \\
0 & -0.021 & 0.016 & -0.035 & 0.031 & -4.574 & 0.000 \\
1 & 0.000 & 0.074 & -0.003 & 0.008 & -0.022 & 0.981 \\
2 & 0.001 & 0.057 & -0.014 & 0.006 & 0.112 & 0.911 \\
\hline
\end{tabular}

Source: Author's Computation

Table 1. Descriptive Statistics for AR of SEOs and t-test

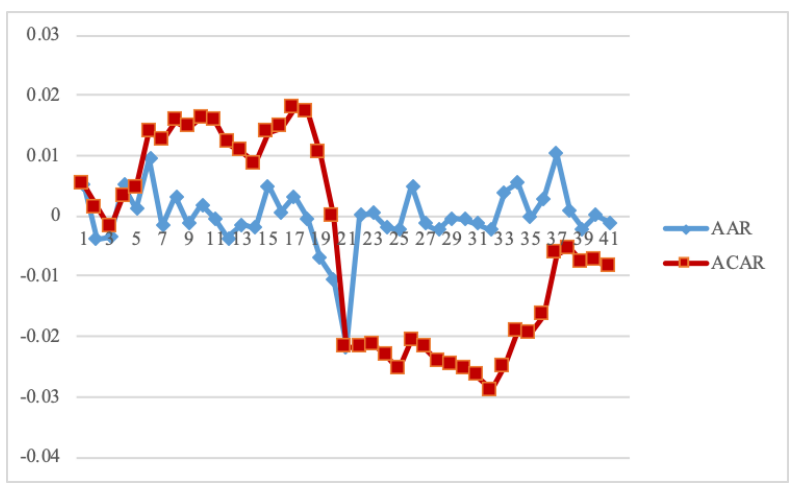

Source: Author's Presentation

Figure 2. AAR and ACAR for SEOs of Public Utility Companies

Therefore, on the day of the issuance announcement and the day before (i.e., day -1 and day 0 ), the average abnormal return (AAR) was negative and significant at 5 percent level, indicating that the market shows negative reaction to the announcement of SEOs.

Figure 2 shows that during the period of the event $(-20,-2)$, the fluctuation rate of the abnormal rate $(A R)$ of return was basically within \pm 0.5 percent. One day before the issuance the average abnormal return (AAR) was non-zero and statistically significant indicating that the market had begun to detect the incidents. On the day of announcement, average abnormal return (AAR) reached -2.18 percent. Moreover, the market was efficient enough to absorb information. The information was 


\section{Zhang}

completely digested on the second day after the announcement, and the abnormal returns were basically returned to \pm 0.5 percent. Similarly, the statistical analysis of the cumulative abnormal return (CAR) is shown as Table 2.

\begin{tabular}{ccccccc}
\hline Event window & Mean & Maximum & Minimum & SD & $\boldsymbol{t}$-value & Sig. \\
\hline$(-20,20)$ & -0.008 & 0.335 & -0.088 & 0.150 & -1.057 & 0.301 \\
$(-15,15)$ & -0.021 & 0.300 & -0.094 & 0.133 & -1.762 & 0.090 \\
$(-10,10)$ & -0.042 & 0.065 & -0.030 & 0.035 & -3.080 & 0.005 \\
$(-5,5)$ & -0.034 & 0.046 & -0.042 & 0.056 & -3.107 & 0.004 \\
$(-1,1)$ & -0.032 & 0.052 & -0.052 & 0.034 & -4.181 & 0.000 \\
$(-20,-2)$ & 0.010 & 0.180 & -0.079 & 0.125 & 0.123 & 0.902 \\
$(2,20)$ & 0.013 & 0.189 & -0.005 & 0.059 & 0.576 & 0.569 \\
\hline Source: Author's Computation & & & & &
\end{tabular}

Table 2. Descriptive Statistics for CAR of SEOs and t-test

It can be summarized that in the event window $(-20,20),(-15,15),(-10,10),(-5,5)$, the cumulative abnormal return CAR is not significantly different from zero, indicating investors have difficulty in obtaining excess returns during such holding period. Moreover, in the period of $(-20,-2)$, CAR is significantly non-zero at the 10 percent level, thus verifying the previous intuitive assumptions, and the news of issuance is not leaked in advance. At the same time, the CAR of the event window ($1,1)$ is significantly non-zero and has the highest confidence. Therefore, to analyze how equity refinancing announcement affects the stock price, the CAR in the $(-1,1)$ window should be selected. In summary, the significant negative value of CAR $(-1,1)$ supports $H_{1}$.

Similarly, to examine the effect of issuing ordinary bonds on stock prices, we determined the issue date of the coupon rate as day 0 , and 20 trading days before and after the event were selected as the event window to investigate the fluctuation law of stock price in these 41 days. AAR and ACAR of these 41 days are shown in Figure 3.

Figure 3 shows that AAR of the public utility listed companies before and after the bond issue date is basically within \pm 0.5 percent. ACAR maintains a positive value throughout the entire event window. There are two significant increases in stock prices in the day -20 and day -2 . The latter wave of rising is easier to understand, owing to the company announced the bond prospectus to transmit new information to the market on day -2 , and investors regard this information as good news. The previous wave of rise is 18 trading days ahead of announcement, which is most likely due to the approval infor- 
mation issued by the listed company for issuing bonds. To this end, this study compared the time difference between the release date and the approval date of the above sample, and got a median of 24 days. After deducting 6 weekend days (non-trading days), the previous inference could be confirmed.

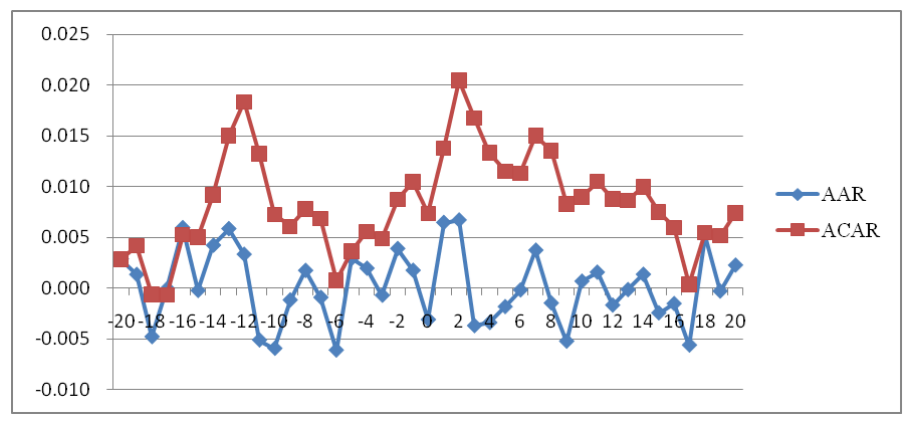

Source: Author's Presentation

Figure 3. AAR and ACAR for Issuing Ordinary Bonds of Public Utility Companies

In order to verify the reliability of the conclusion drawn from a statistical point of view, a two-tailed $t$-test was adopted to test whether the mean of the single-day abnormal return (AR) and the cumulative abnormal return (CAR) are zero. The results are shown in Table 3 and Table 4, respectively. The empirical results show that AAR of trading days in the event window is not significant except day 2. Only ACAR in the event window $(-2,2)$ passes the $t$-test at 10 percent significance level. Moreover, although ACAR of $(-18,-12)$ interval shown in Figure 3 continues to rise, it is not significant at 10 percent level. The main reason is that individual stocks are scattered and their cumulative abnormal return variance is large. However, ACAR in the event window $(-2,2)$ is significant at 10 percent level. It can be concluded that although the announcement effect of issuing bonds by public utility listed companies is moderate, there is still a positive announcement effect. In summary, this finding supports $\mathrm{H}_{2}$.

As for issuing convertible bonds, scholars often take the announcement day of the issuance plan or the announcement of issuance as the event day to examine the announcement effect of issuing convertible bonds. The reason is that the announcement day of issuance plan is the first time that the market is informed of the information on the issuance of convertible bonds by listed companies. As of the date of the announcement, the market can obtain comprehensive information on the issuance of convertible bonds through the bond offering instructions provided by the listed company and the final coupon rate. Therefore, the issue announcement date is also an important point in time. Therefore, 


\section{Zhang}

this study separately studied the announcement effects of these two event days.

\begin{tabular}{ccccccc}
\hline Relative date & Mean & Maximum & Minimum & SD & $\boldsymbol{t}$-value & Sig. \\
\hline-2 & 0.000 & 0.059 & -0.026 & 0.017 & 1.062 & 0.299 \\
-1 & -0.002 & 0.085 & -0.026 & 0.023 & 0.366 & 0.717 \\
0 & -0.004 & 0.018 & -0.037 & 0.012 & -1.190 & 0.246 \\
1 & 0.002 & 0.078 & -0.032 & 0.021 & 1.456 & 0.158 \\
2 & 0.007 & 0.030 & -0.035 & 0.014 & 2.328 & 0.029 \\
\hline
\end{tabular}

Source: Author's Computation

Table 3. Descriptive Statistics for AR of Issuing Ordinary Bonds and t-test

\begin{tabular}{ccccccc}
\hline Event window & Mean & Maximum & Minimum & SD & $t$-value & Sig. \\
\hline$(-1,1)$ & 0.005 & 0.101 & -0.068 & 0.037 & 0.652 & 0.520 \\
$(-2,2)$ & 0.015 & 0.146 & -0.058 & 0.045 & 1.696 & 0.093 \\
$(-5,5)$ & 0.010 & 0.147 & -0.086 & 0.051 & 1.068 & 0.295 \\
$(-10,10)$ & -0.004 & 0.184 & -0.271 & 0.092 & -0.235 & 0.815 \\
$(-20,20)$ & 0.007 & 0.208 & -0.285 & 0.110 & 0.320 & 0.751 \\
$(-18,-12)$ & 0.014 & 0.229 & -0.071 & 0.062 & 1.104 & 0.280 \\
\hline
\end{tabular}

Source: Author's Computation

Table 4. Descriptive Statistics for CAR of Issuing Ordinary Bonds and t-test

In order to enhance the reliability of this study, the single-sample $t$-test and Wilcoxon signed rank test were used to measure the significance level of the single-day abnormal return (AR). The result of the analysis is shown in Table 5, wherein, $p$-value represents the level of significance given by the one-sample $t$-test, and Sig. is the level of significance given by the Wilcoxon signed rank test. The results are not much different. For the reason, this study performed a Kolmogorov-Smirnov (K-S) test on the above samples. At the 5 percent significance level, the null hypothesis that the listed company's single-day abnormal return (AR) obeys the normal distribution cannot be rejected. It can be summarized that although the sample size of convertible bonds is small, it still obeys the normal distribution, and the sample satisfies the assumptions of $t$-test and Wilcoxon test at the same time. Therefore, we can conclude that AAR is close to zero on the plan announcement day, which is not significantly different from zero as well. AAR is -0.22 percent on the issuance day but it is not signific- 
antly different from zero. In summary, our finding supports $\mathrm{H}_{3}$.

\begin{tabular}{ccccccc}
\hline \multirow{2}{*}{$\begin{array}{c}\text { Relative } \\
\text { date }\end{array}$} & \multicolumn{3}{c}{ Plan announcement day } & \multicolumn{3}{c}{ Issuance announcement day } \\
\cline { 2 - 7 } & Mean & $\boldsymbol{p}$-value & Sig. & Mean & $\boldsymbol{p}$-value & Sig. \\
\hline-4 & 0.011 & 0.135 & 0.198 & 0.004 & 0.280 & 0.245 \\
-3 & -0.010 & 0.068 & 0.074 & 0.006 & 0.208 & 0.221 \\
-2 & 0.006 & 0.364 & 0.730 & 0.014 & 0.048 & 0.056 \\
-1 & 0.003 & 0.643 & 0.778 & -0.004 & 0.344 & 0.397 \\
0 & 0.000 & 0.944 & 0.925 & -0.002 & 0.829 & 0.826 \\
1 & -0.000 & 0.960 & 0.925 & -0.003 & 0.547 & 0.826 \\
2 & 0.006 & 0.264 & 0.551 & 0.005 & 0.527 & 0.433 \\
3 & -0.000 & 0.936 & 0.975 & 0.002 & 0.791 & 0.826 \\
4 & -0.002 & 0.569 & 0.594 & -0.010 & 0.105 & 0.221 \\
\hline
\end{tabular}

Source: Author's Computation

Table 5. Descriptive Statistics for AR of Issuing Convertible Bonds, t-test, and Wilcoxon Signed Rank Test

CAR of different event windows and its significance level are summarized as shown in Table 6 . It could be found that the announcement effect of issuing convertible bonds are not significant on both kinds of announcement date, and its directionality is related to the selection of the event window.

\begin{tabular}{ccccccc}
\hline \multirow{2}{*}{ Event window } & \multicolumn{3}{c}{ Plan announcement day } & \multicolumn{3}{c}{ Issuance announcement day } \\
\cline { 2 - 6 } & Mean & $\boldsymbol{p}$-value & Sig. & Mean & $\boldsymbol{p}$-value & Sig. \\
\hline$(-1,1)$ & 0.004 & 0.751 & 0.875 & -0.009 & 0.461 & 0.594 \\
$(-2,2)$ & 0.017 & 0.311 & 0.300 & 0.010 & 0.423 & 0.510 \\
$(-5,5)$ & 0.018 & 0.180 & 0.158 & 0.021 & 0.129 & 0.300 \\
$(-10,10)$ & 0.004 & 0.782 & 0.730 & -0.005 & 0.736 & 0.826 \\
$(-20,20)$ & -0.016 & 0.442 & 0.300 & 0.002 & 0.952 & 0.975 \\
\hline
\end{tabular}

Source: Author's Computation

Table 6. Descriptive Statistics for CAR of Issuing Convertible Bonds, t-test, and Wilcoxon Signed Rank Test

\section{DISCUSSION}

To answer the question whether and how corporate refinancing affects the firm value/shareholder value within the public utility industry, this study documents significant findings that for SEOs, the CAR in the 


\section{Zhang}

$(-1,1)$ window is -3.21 percent. For issuing ordinary bonds, the CAR in the $(-2,2)$ window is 1.52 percent. These results support the information asymmetry theory and signaling theory, which imply that debt issuance would be beneficial to shareholder value whilst equity issuance would be detrimental to shareholder value.

\section{CONCLUSION}

Using the event study methodology, this study employs empirical analysis on the announcement effect of secondary equity offerings (SEOs), issuing ordinary bonds, and issuing convertible bonds measured by abnormal returns and cumulative abnormal returns. This study discovered that SEOs has a significantly negative announcement effect, issuing ordinary bonds has a significantly positive announcement effect, and issuing convertible bonds has insignificant announcement effect. The finding is similar to those of research on Chinese stock market as a whole in term of trend but are smaller in term of magnitude (Asquith and Mullins, 1986; Masulis and Korwar, 1986).

\section{IMPLICATIONS}

The findings of this study indicate that debt issuance conveys good signals of firm operations to external investors whilst equity issuance conveys bad signals. As convertible bonds have characteristics of both equity and bonds, issuing convertible bonds conveys mixed information to the capital markets.

This study provides several substantial practical implications for corporate management. Our results indicate that SEOs are associated with negative market reactions and issuing bonds convey positive signals to the markets. The results of this study show market exclusion of equity refinancing. Comparatively, announcement effect of issuing ordinary bonds is positive at 10 percent significant level, owing to the stable income of the public utility industry, the high cash flow and creditor requirements for creditors, and thus easy to obtain market recognition. Moreover, the announcement effect of issuing convertible bonds is basically between the announcement effect of SEOs and issuing ordinary bonds. Therefore, it is necessary to promote the market-oriented reform of the public issuance and issuance system. It can be inferred that only by maintaining the smooth flow of credit financing channels can public utility companies adjust their capital structure through debt financing in a timely and appropriate manner.

\section{LIMITATIONS AND FUTURE DIRECTIONS}

This study also has some limitations. Due to the marginal changes in the firm size across listed public 
International Journal of Management, Economics and Social Sciences

utility companies in China and the low level of interest rate marketization, this study cannot verify the impact of firm size and relative financing costs on the announcement effect. Therefore, for future studies, it would be meaningful and beneficial for researchers to investigate the association between change in market interest rate and the announcement effect. Moreover, researchers can also examine the impact of firm size on announcement effect with a larger sample of homogeneous firms.

\section{REFERENCES}

Abdul Rahim, N., Goodacre, A. \& Veld, C. (2012). Wealth effects of convertible bond and warrant-bond offerings: A meta analysis. The European Journal of Finance, 20(4): 380-398. https://doi.org/10.1080/1351847X.2012.712920

Ammann, M., Blickle, K. \& Ehmann, C. (2017). Announcement effects of contingent convertible securities: Evidence from the global banking industry. European financial management, 23(1): 127-152. https://doi.org/10.1111/eufm.12092

Asquith, P. \& Mullins Jr, D. W. (1986). Equity issues and offering dilution. Journal of Financial Economics, 15(1-2): 61-89.

Ball, R. \& Brown, P. (1968). An empirical evaluation of accounting income numbers. Journal of Accounting Research, 6(2): 159-178.

Bartov, E., Lindahl, F. W. \& Ricks, W. E. (1998). Stock price behavior around announcements of write-offs. Review of Accounting Studies, 3(4): 327-346.

Booth, L. \& Chang, B. (2011). Information asymmetry, dividend status, and SEO announcement-day returns. Journal of Financial Research, 34(1): 155-177. https://doi.org/10.1111/j.1475-6803.2010.01287.x

Brav, A., Geczy, C. \& Gompers, P. A. (2000). Is the abnormal return following equity issuances anomalous? Journal of Financial Economics, 56(2): 209-249.

Brown, S. J. \& Warner, J. B. (1980). Measuring security price performance. Journal of Financial Economics, 8(3): 205-258. https://doi.org/10.1016/0304-405X(80)90002-1

Brown, S. J. \& Warner, J. B. (1985). Using daily stock returns: The case of event studies. Journal of Financial Economics, 14(1): 3-31.

Chang, C. C., Kam, T. Y., Chien, C. C. \& Su, W. T. (2019). The Impact of financial constraints on the convertible bond announcement returns. Economies, 7(2): 32-40.

Chen, X., Lee, C. W. J. \& Li, J. (2008). Government assisted earnings management in China. Journal of Accounting and Public Policy, 27(3): 262-274.

Cheng, Y. S., Liu, Y. P. \& Chien, C. Y. (2010). Capital structure and firm value in China: A panel threshold regression analysis. African Journal of Business Management, 4(12): 2500-2507.

Chin, S. K. \& Abdullah, N. A. (2013). Announcements effect of corporate bond issuance and its determinants. Contemporary Economics, 7(1): 5-18.

Cuong, N. T. (2014). Threshold effect of capital structure on firm value. International Journal of Finance and Banking Studies, 3(3): 14-29.

Danielova, A. N. \& Smart, S. B. (2012). Stock price effects of mandatory exchangeable debt. International Advances in Economic Research, 18(1): 40-52. https://doi.org/10.1007/s11294-011-9337-9

Danis, A., Rettl, D. A. \& Whited, T. M. (2014). Refinancing, profitability, and capital structure. Journal of Financial Economics, 114(3): 424-443. https://doi.org/10.1016/j.jfineco.2014.07.010

Di Maggio, M., Kermani, A. \& Palmer, C. J. (2020). How quantitative easing works: Evidence on the refinancing channel. The Review of Economic Studies, 87(3): 1498-1528. https://doi.org/10.1093/restud/rdz060

Dong, M., Hirshleifer, D. \& Teoh, S. H. (2012). Overvalued equity and financing decisions. The Review of Financial Studies, 25(12): 3645-3683

Dolley, J. C. (1933). Common stock split-ups-motives and effects. Harvard Business Review, 12(1): 70-81.

Duca, E., Dutordoir, M., Veld, C. \& Verwijmeren, P. (2012). Why are convertible bond announcements associated with increasingly negative issuer stock returns? An arbitrage-based explanation. Journal of Banking and Finance, 36(11): 28842899. https://doi.org/10.1016/j.jbankfin.2012.03.019

Friewald, N., Nagler, F. \& Wagner, C. (2018). Debt refinancing and equity returns. Available at SSRN 2684462. http://dx.doi.org/10.2139/ssrn.2684462

Haw, I. M., Ho, S. S., Hu, B. \& Zhang, X. (2011). The contribution of stock repurchases to the value of the firm and cash holdings around the world. Journal of Corporate Finance, 17(1): 152-166.

Hossain, A. T. \& Nguyen, D. X. (2016). Capital structure, firm performance and the recent financial crisis. Journal of Accounting and Finance, 16(1): 76-89.

Ibhagui, O. W. \& Olokoyo, F. O. (2018). Leverage and firm performance: New evidence on the role of firm size. The North American Journal of Economics and Finance, 45, 57-82.

Kim, H. J. \& Han, S. H. (2019). Convertible bond announcement returns, capital expenditures, and investment opportunities: Evidence from Korea. Pacific-Basin Finance Journal, 53(2): 331-348. https://doi.org/10.1016/j.pacfin.2018.11.007 


\section{Zhang}

Li, H., Liu, H., Siganos, A. \& Zhou, M. (2016). Bank regulation, financial crisis, and the announcement effects of seasoned equity offerings of US commercial banks. Journal of Financial Stability, 25(3): 37-46. https://doi.org/10.1016/j.jfs.2016.06.007

Lucas, D. J. \& McDonald, R. L. (1990). Equity issues and stock price dynamics. The Journal of Finance, 45(4): 1019-1043. https://doi.org/10.1111/j.1540-6261.1990.tb02425.x

Masulis, R. W. \& Korwar, A. N. (1986). Seasoned equity offerings: An empirical investigation. Journal of Financial Economics, 15(1-2): 91-118.

Moldogaziev, T. T. \& Luby, M. J. (2012). State and local government bond refinancing and the factors associated with the Refunding Decision. Public Finance Review, 40(5): 614-642. https://doi.org/10.1177/1091142111430954

Myers, S. C. \& Majluf, N. S. (1984). Corporate financing and investment decisions when firms have information that investors do not have. Journal of Financial Economics, 13(2): 187-221.

Ross, S. A. (1977). The determination of financial structure: the incentive-signaling approach. The Bell Journal of Economics, 8(1): 23-40.

Sam, A. G. \& Zhang, X. (2020). Value relevance of the new environmental enforcement regime in China. Journal of Corporate Finance, 62, 101573

Shahid, H., Xinping, X., Mahmood, F. \& Usman, M. (2010). Announcement effects of seasoned equity offerings in China. International Journal of Economics and Finance, 2(3): 163-169.

Sheikh, N. A. \& Wang, Z. (2011). Determinants of capital structure. Managerial Finance, 37(2): 117-133.

Suwanna, T. (2012). Impacts of dividend announcement on stock return. Procedia-Social and Behavioral Sciences, 40, 721725. 